derance of papers on the laboratory rat. BBR has attracted a wider range of contributors and of species, in keeping with its declared aims of being both interdisciplinary and comparative. It has also established a very effective balance between continental European and AngloSaxon contributions, although all papers are in English.

The papers in BBR could probably all have found quite suitable homes in previously existing journals, but it is quite clear that the new journal has its own distinctive flavour, and may serve as a focus for a particular growing international and interdisciplinary research community.

Oliver Braddick is a Lecturer in Experimental Psychology at the University of Cambridge.

\section{Methods' Reading}

\section{D.W. Richter}

Journal of Neuroscience Methods. Editorin-chief J.S. Kelly. $8 / \mathrm{yr}$ in 2 vols. (Elsevier/North-Holland Biomedical.) Dfl. 404.

THE editors of the Journal of Neuroscience Methods (JNM) at one time expressed the rather ambitious hope that future Nobel Prize winners would later be seen to have published papers in their journal. This optimism may even be fulfilled - JNM has already carried contributions of some worth, matched by excellent standards of production.

The journal publishes reviews, research papers and "comments", the latter in a camera-ready format. Publication is rapid (four to six months in 1981). Its wideranging brief is to provide a forum for techniques

used to investigate the organisation and fine structure, biochemistry, histo- and cytochemistry, physiology, biophysics and pharmacology of receptors, neurones, synapses and glial cells in the nervous system ... or applicable to the clinical and behavioural sciences, tissue culture, neurocommunications, biocybernetics or computer software.

Thus it supplies a much-needed home for technical papers and to date a large variety of contributions have appeared which cover a broad area of neuroscience. The quality of both papers and reviews is in general high and it seems likely that the editors' other ambition that the papers collectively summarize the state of the art will be realized. For the present, scientists working in the field of neurosciences should realize that an important new journal has appeared - and that they will have to spend even more hours reading.

D.W. Richter is Professor of Physiology at the Physiological Institute of the University of Heidelberg.

\title{
Autonomic Specialization
}

\section{K.M. Spyer}

Journal of the Autonomic Nervous System. Editor-in-chief C. McC. Brooks. $6 / \mathrm{yr}$ in 2 vols. (Elsevier/North-Holland Biomedical). Dfl. 404.

THE reasons for founding the Journal of the Autonomic Nervous System (JANS) were enunciated in an editorial in the first issue, and a sentence from the opening paragraph gives the journal's raison d'être: "The increasing awareness of the integrative function of the autonomic nervous system, of its service to all body parts, and of its involvement in all body functions inspired this move'". To this end, JANS publishes brief communications, full papers and reviews on any subject concerning the structure and function of the autonomic nervous system.

The editorial statement, however, brings into question the validity of developing a specialized journal, removing discussion of the subject from its natural home in the established journals of physiology and the neurosciences. No doubt as a consequence, this has led to the rather uneven and unimpressive standard of the contributions published so far. There have been few incisive papers, many articles falling into the category of being mildly interesting but unimaginative, since they follow established conventions and paths taken by their authors in papers published elsewhere.

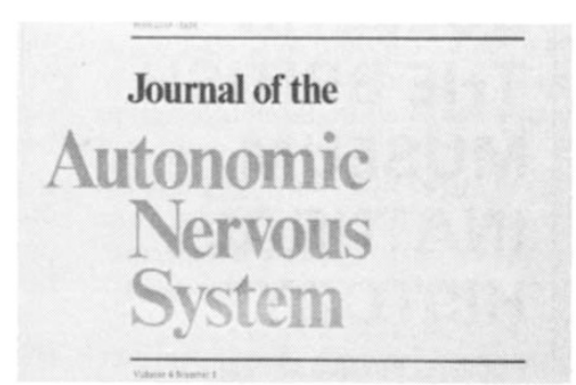

I feel that it remains to be proved on the basis of the limited available evidence that an independent journal subserving this area of investigation is really necessary. The many other journals of physiology and neuroscience appear to remain the journals of choice of accepted leaders in the field, including many members of the editorial board of JANS itself. This is surely correct, as a dissociation of research on the autonomic nervous system from the mainstream of physiological investigation and publication would be a regressive step. The journal would seem to have a better future in acting as a forum for brief reviews and the publication of the proceedings of international symposia; in the latter case a successful issue has recently appeared.

K.M. Spyer is Professor and Head of the Physiology Department at the Royal Free Hospital School of Medicine, London.

\section{Human Sociobiology in Adolescence}

\section{Robert Attenborough}

Journal of Social and Biological Structures. Editors H. Wheeler and J.F. Danielli. 4/yr. (Academic.) $£ 40$ UK, \$106 elsewhere. Ethology and Sociobiology. Editors-in-chief M.T. McGuire and N.G. Blurton Jones. 4/yr. (Elsevier/NorthHolland Biomedical.) $\$ 88$.

SINCE 1975, when E.O. Wilson drew attention to arguments about social behaviour that originate from evolutionary biology, sociobiology has been transformed from a subject of rather specialized concern to one on which many people have something to say. Within zoology, sociobiological papers now appear both in established ethological journals such as Animal Behaviour, and in newer ones such as Behavioural Ecology and Sociobiology. In the human sciences, however, there has been no obvious outlet for such papers, which have therefore been dispersed through the zoological, anthropological and other literature. The two journals under review here are designed to fill this gap by focusing on sociobiological and ethological papers dealing with or relevant to human societies.

The journals have some similarities. Both are cross-disciplinary, and have had some success in persuading distinguished and able members of the contributing disciplines to write for them and join their editorial boards; both publish short and long papers, book reviews and other short items. Per page, the two offer similar value for money. Not surprisingly, the papers themselves are diverse in approach and

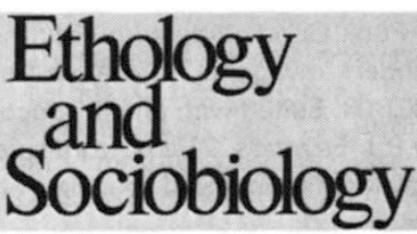

variable in quality, and they contain a good deal that is theoretical and speculative. As yet, neither journal has published much serious criticism of sociobiology, which is unfortunate, given the controversies surrounding the field. But undoubtedly the best contributions are of real interest.

Journal of Social and Biological Structures (JSBS) may seem a curious title 